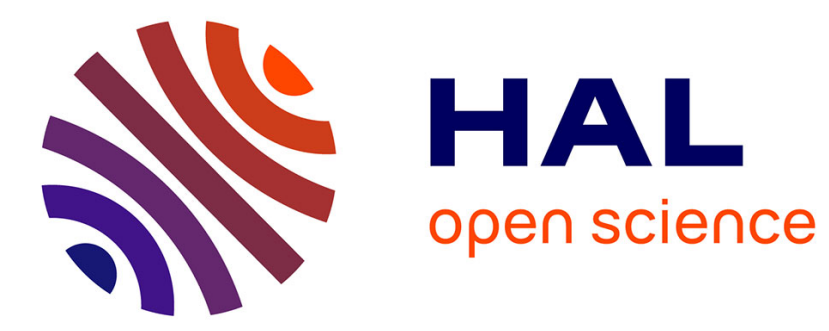

\title{
Technological interdependence between south american countries: a spatial panel data growth model
}

\author{
Carolina Guevara, Corinne Autant-Bernard
}

\section{To cite this version:}

Carolina Guevara, Corinne Autant-Bernard. Technological interdependence between south american countries: a spatial panel data growth model. 2013. halshs-00803541

\section{HAL Id: halshs-00803541 \\ https://shs.hal.science/halshs-00803541}

Preprint submitted on 22 Mar 2013

HAL is a multi-disciplinary open access archive for the deposit and dissemination of scientific research documents, whether they are published or not. The documents may come from teaching and research institutions in France or abroad, or from public or private research centers.
L'archive ouverte pluridisciplinaire HAL, est destinée au dépôt et à la diffusion de documents scientifiques de niveau recherche, publiés ou non, émanant des établissements d'enseignement et de recherche français ou étrangers, des laboratoires publics ou privés. 
Technological interdependence between south american countries : a spatial panel data growth model

Carolina Guevara, Corinne Autant-Bernard

March 2013 


\section{GATE Groupe d'Analyse et de Théorie Économique Lyon-St Étienne}

93, chemin des Mouilles 69130 Ecully - France

Tel. +33(0)4 72866060

Fax $+33(0) 472866090$

6, rue Basse des Rives 42023 Saint-Etienne cedex 02 - France

Tel. +33 (0)4 77421960

Fax. +33 (0)4 77421950

Messagerie électronique / Email : gate@gate.cnrs.fr

Téléchargement / Download : http://www.gate.cnrs.fr - Publications / Working Papers 


\title{
TECHNOLOGICAL INTERDEPENDENCE BETWEEN SOUTH AMERICAN COUNTRIES: A SPATIAL PANEL DATA GROWTH MODEL
}

\author{
Carolina Guevara and Corinne Autant-Bernard
}

\author{
Université de Lyon, Lyon, F-69007, France ; Université Jean Monnet, Saint-Etienne, F-42000, \\ France ; CNRS, GATE Lyon Saint-Etienne, Ecully, F-69130, France. \\ grace.carolina.guevara.rosero@univ-st-etienne.fr, corinne.autant@univ-st-etienne.fr
}

\begin{abstract}
:
This study examines how the dissemination of research and development (R\&D) and technology affected economic performance in different South American countries from 1990 to 2010. The objective is to understand the relationship between countries in the process of international technology diffusion, i.e. measuring externalities and identifying the mechanisms through which technology is transferred.

To answer these questions, we consider the Schumpeterian growth model proposed by Ertur and Koch (2011). This framework accounts for the interdependences between countries (resulting from R\&D externalities) from both a theoretical and an empirical point of view. With this spatial panel model, we assess the extent to which one country's productivity affects the productivity of other countries in the region and test the effectiveness of R\&D in terms of direct and indirect impact on the economy. Different specifications of the spatial weight matrix are considered in order to investigate the different mechanisms of technological diffusion.

The originality of this study lies firstly through the use of $R \& D$ measures that allow different sources of funding to be distinguished. In particular, we can thus assess the role of $R \& D$ expenditure from national sources in comparison with $R \& D$ expenditure from foreign sources which, in the context of developing countries, is a key issue. In addition, we provide an assessment of the role of absorptive capacity in terms of research expenditure or investment in human capital on the productivity levels of countries in the region.

The results suggest that of the various factors determining South America's economic performance, public sector funded R\&D investments and, to a lesser extent, private sector funded $\mathrm{R} \& \mathrm{D}$, have a positive impact on these countries' productivity. In contrast, however, foreign investment in research does not produce the expected benefits. We also observe that there are significant international spillovers from $\mathrm{R} \& \mathrm{D}$ activities. The ability to disseminate technologies and to take advantage of these international spillovers, however, differs from one country to another. Our estimates indicate that Brazil has positioned itself as the main actor in the region in terms of technological diffusion, while Bolivia is the country most likely to benefit from these spillover effects.
\end{abstract}




\section{Résumé:}

Cette étude examine comment la diffusion de la recherche et développement (R\&D) et de la technologie affecte la performance économique dans les différents pays d'Amérique du Sud au cours de la période 1990-2010. L'objectif est de comprendre les relations entre pays dans le processus de diffusion technologique internationale, c'est-à-dire mesurer les externalités et d'identifier les mécanismes par lesquels la technologie est transférée.

Pour répondre à ces questions, nous considérons le modèle de croissance schumpétérien proposé par Ertur et Koch (2011). Ce dernier rend compte, d'un point de vue théorique comme d'un point de vue empirique, de l'interdépendance entre pays résultant des retombées de la R\&D. Grâce à ce modèle de panel spatial, nous évaluons dans quelle mesure la productivité d'un pays affecte la productivité des autres pays de la région, et nous testons l'efficacité des dépenses de $\mathrm{R} \& \mathrm{D}$, en termes d'impact direct et indirect sur l'économie. Différentes spécifications de la matrice de pondération spatiales sont considérées afin de rendre compte des différents mécanismes de diffusion technologique.

L'originalité de cette étude réside tout d'abord dans la mise en place de mesures de R\&D permettant de distinguer différentes sources de financement. Ainsi, nous pouvons en particulier identifier le rôle de la $R \& D$ financée par des sources nationales relativement au rôle des activités de $R \& D$ financées par des sources étrangères, ce qui constitue, dans le contexte de pays en développement, un enjeu tout à fait essentiel. En outre, nous fournissons une évaluation du rôle des capacités d'absorption, en termes de dépenses de recherche ou d'investissement en capital humain, sur les niveaux de productivité des pays de cette région.

Les résultats suggèrent que parmi les différents déterminants de la performance des économies d'Amérique du Sud, les investissements en R\&D financés par la sphère publique, et dans une moindre mesure par la sphère privée, ont un impact positif à la fois sur la productivité de ces pays. En revanche, les investissements étrangers en matière de recherche ne produisent pas les effets bénéfiques attendus. Nous observons également qu'il existe des retombées internationales importantes issues des activités de R\&D. Toutefois, la capacité à diffuser des technologies et à tirer profit de ces retombées internationales diffère d'un pays à l'autre. Nos estimations montrent que le Brésil se positionne comme le leader de la région en termes de diffusion technologique tandis que la Bolivie serait le pays plus enclin à bénéficier de ces effets d'entrainement.

Keywords: Total Factor Productivity, Technology diffusion, spatial panel model

JEL Codes: O3, O4, R11 


\section{INTRODUCTION}

Much research has focused on the impact of innovation and technology upon economic performance. It has been noted that country growth cannot be explained by factor accumulation alone. Several factors impact on changes in economies' production levels, including advances in technology, changes in externalities, and changes in the composition of production sectors. Another important factor influencing the differences in economies is organisational change such as the adoption of lower cost production methods through investment in Research and Development (R\&D), Information and Communications Technology (ICT), and other measures. Productivity differences thus explain a large part of the income differences across countries and technology plays a key role in determining such productivity. Nowadays, only a small group of rich countries account for most of the world's new technology creation. ${ }^{1}$ The pattern of worldwide technical change is therefore determined in large part by international diffusion. Two important aspects have to be considered in studying international technology diffusion: first, what determines the extent of international technology diffusion and, secondly, what are the channels through which technology is spread? It is important to note that even though international technology diffusion is increasing in relative terms, technology diffusion is neither inevitable nor automatic: investment in domestic technology is necessary (Keller, 2004). The aim of this study is to shed light upon about what has happened in South American countries with respect to the importance of technology and the role of R\&D investment in the productivity of their economies.

This region has recently faced significant changes in terms of growth. Both the level of growth and the intensity of its technological component have increased. This can be observed through three main stylised facts. First of all, the regional average of R\&D per GDP ratio in 1990 was $0.09 \%$. In 2000 this figure was $0.18 \%$ and by the year 2010 , it had increased to $0.33 \%$. $^{2}$ Of the countries in the region, Argentina and Brazil exhibit the highest level of R\&D per GDP. Brazil prominently increased its R\&D expenditure, reaching 1.18\% of GDP in 2010.

Secondly, a sustained policy of increased openness to foreign trade and foreign direct investment (FDI) has increased countries' exposure to technology. Imports of manufactured goods into South American countries grew at a rate of $4 \%$ between 1990 and $2010 .{ }^{3}$ Within these imports, the proportion of technological product also increased. Although the ratio of high-tech imports ${ }^{4}$ to total imports remains limited (13.3\%), this proportion increased by four percentage points between 1990 and 2008. The ratio of medium-high-tech goods ${ }^{5}$ to total imports was high, at

\footnotetext{
${ }^{1}$ The G-7 countries (the largest seven industrialised countries) accounted for around $84 \%$ of the world's R\&D spending in 1995 .

${ }^{2}$ The calculations are made without Peru for each year, and without Venezuela for 2010, because R\&D data are not available for these countries for these dates. In addition, Venezuela data for 1990 and 2000 correspond to the STA indicator, considered as an approximation of R\&D. The data were collected from the RICYT (Iberoamerican and Interamerican Network of Science and Technology Indicators) database which is based on the Frascati Manual of OECD countries.

${ }^{3}$ Calculations based on the World Bank's World Development Indicators.

${ }^{4}$ High-technology aggregation includes manufacture of medicinal and pharmaceutical products, chemical materials and products, armaments, manufacture of computer, electronic and optical products, scientific instruments, and manufacture of air and spacecraft and related machinery and electric energy.

${ }^{5}$ The medium-high-technology aggregation includes manufacture of chemical elements and compounds, manufacture of weapons and ammunition, manufacture of electrical equipment, manufacture of machinery and non
} 
$38.2 \%$ and $39.6 \%$ respectively in 1990 and 2008. The increasing proportion of these types of products within total imports could be fairly significant in terms of technology diffusion within South America.

On the export side, the proportion of high-technology goods is much lower in comparison to imports at only 4\%, demonstrating that South American countries have not yet developed the capacity to invent entirely new technologies. Nevertheless, the sector has experienced a drastic increase over the last two decades, as this amounted to only $2.3 \%$ in 1990 . With respect to the export of medium-high-technology goods, again, this is lower than the percentage imported. Yet, this sector grew from $9.2 \%$ in 1990 to $13.4 \%$ in 2008. Medium-low-technology exports thus contribute significantly to the total exports from South American countries, which mainly consist of transport equipment and petroleum products. One interpretation of this is that it could be the result of absorptive capacity. When a country successfully replicates and adapts pre-existing technology, the technology is first produced domestically. Once international standards are reached, it can then be exported, as a consequence of the country's absorption capacity.

Despite these changes, important challenges remain for South American countries, particularly in terms of improving quality of life and reducing poverty, unemployment and inequality in income distribution. Beyond having more resources, it is also important to foster economic diversification and competitiveness through investment in infrastructure, education and innovation. Failure to act now will result in these economies continuing to concentrate on primary products with low added value. Hence the importance of studying the role of innovation, $\mathrm{R} \& \mathrm{D}$, and technology diffusion in the economic growth of South American countries.

Given this context, we are interested in investigating how technology diffusion operates in South America, i.e. in measuring knowledge externalities or spillovers and identifying the mechanisms through which technology is transferred. To this aim, we consider the multi-country Schumpeterian growth model proposed by Ertur and Koch (2011). This framework allows us to take into account the interdependences between countries resulting from $R \& D$ externalities. Based on a spatial panel model, we assess the extent to which a country's productivity affects the productivity of other countries in the region, and we test the effectiveness of R\&D in terms of direct and indirect impacts on the economy. Moreover, in order to investigate the different mechanisms for technological diffusion, different specifications of the spatial weight matrix are considered. In comparison with Ertur and Koch (2011), the originality of this study lies firstly in the use of R\&D measures which allow different sources of funding to be differentiated. Thus, we can compare the role of $R \& D$ expenditure from national sources with the role of $R \& D$ expenditure from foreign sources which is, in the context of developing countries, a key issue. In addition, we rely on panel data from 1990 to 2010, allowing us to control for unobserved country specific effects.

The remainder of this paper is organised as follows. The first section presents the theoretical framework. Endogenous growth models are shown to be adequate to explain growth in South American countries and the main building blocks of our spatially augmented Solow model are set out. In the second section, the empirical specification of our Total Factor Productivity (TFP)

electrical equipment, manufacture of motor vehicles, trailers and semi-trailers, and manufacture of other transport equipment. 
equation implied by the multi-country Schumpeterian model is discussed and the econometric methodology is introduced. Since we have a panel database for South American countries, the growth model examined in this study requires spatial panel econometrics tools. In the third section, data sources and criteria used to construct the spatial weight matrices are explained. The fourth section contains the econometric results from our multi-country Schumpeterian growth model. In this part, international R\&D spillovers are calculated, providing an assessment of the intensity of $R \& D$ relationships between South American countries. The results suggest that of the various determinants of South American economic performance, public sector funded R\&D and, to a lesser extent, private sphere funded $R \& D$, have a positive impact on the productivity of these countries. In contrast, however, foreign investment in research does not produce the expected benefits. We also observe that there are significant international spillovers from $R \& D$ activities, although the ability to disseminate technologies and to take advantage of these international spillovers differs from one country to another. Our estimates indicate that Brazil has positioned itself as the main actor in the area in terms of technological diffusion, while Bolivia is the country most likely to benefit from these international spillover effects. Finally, in the last section, the conclusions of the study and recommendations for broadening its scope are presented. Some relevant policy recommendations for the target countries are also suggested.

\section{Theoretical framework: Ertur and Koch's multi-country Schumpeterian growth model}

From a theoretical perspective, the ability to investigate the impact of technological progress and technological diffusion on growth processes dates back to the development of endogenous growth models. In new growth theory, models have a common structure which can be discerned by considering a standardised version of Aghion and Howitt's 1998 model and Howitt's 2000 model. The mechanism of endogenous growth which they consider is international technology diffusion in the Schumpeterian growth model. Their model can justifiably be called "neoSchumpeterian' because it takes account of the process of creative destruction and the devaluation of previous technologies through obsolescence (Michl, 2000).

Invention is modelled as a Poisson process, with an arrival rate depending on the resources devoted to $R \& D$. The amount of resources devoted to research corresponds to an arbitrage condition equating the marginal cost of the research with its marginal value (Howitt, 2000). $\mathrm{R} \& \mathrm{D}$ investment increases the general stock of knowledge. This in turn makes it less costly to undertake further research and increases the productivity of other inputs and outputs (Grossman and Helpman, 1991). Such knowledge spillovers may arise both within and between countries.

Endogenous growth models have therefore been used to study international spillovers. Bianco and Niang (2012) analysed the role of international spillovers in generating gains for a panel of 24 OECD countries. They found that substantial cross-country spillovers occur, mainly relating to R\&D and human capital variables, which contribute significantly to productivity. Coe and Helpman (1995) and Eaton and Kortum (1996) also studied international knowledge spillovers and showed that such spillovers are not symmetrical. Coe and Helpman (1995) found that in developed countries intra-national spillovers affected economic growth, although international spillovers had little effect on growth. In contrast, they found that in developing countries, 
international spillovers from developed countries had an important effect on growth, as did intranational spillovers.

Given that South American countries participate in the new pattern of global growth as they make technical advances, endogenous growth models are suitable for studying their growth. In addition, endogenous growth theory is concerned with the determination of long term growth rates and this work focuses on how South America's economic structure helps its development. To some extent, the countries of South America are part of endogenous development. They may generate externalities which lead to increasing returns insofar as technology diffusion and absorptive capacity are efficient. Hence, in this study, the endogenous growth model is tested for South America.

From this perspective, the model proposed by Ertur and Koch (2011) is used, in order to fully account for spatial dependencies among countries. The model proposed by Ertur and Koch (2011) is based on the multi-country Schumpeterian growth model developed by Aghion and Howitt (1998) and Howitt (2000). In the Schumpeterian growth model, R\&D expenditure is motivated by profit and the distribution of countries' technology depends on their R\&D expenditure. In this model, the effect of technology diffusion on research productivity implies convergence on the same growth rate and parallel growth paths in the long term. Ertur and Koch's contribution is to increase the research productivity function of endogenous growth models by adding a general process of technological interdependence. This leads to a spatial econometric reduced form which is somewhat latent and not fully exploited by Aghion and Howitt (1998) or Howitt (2000). The empirical specification proposed by Aghion and Howitt (1998) or Howitt (2000) thus appears to be mis-specified, since it omits this interdependence, which is fundamental in their theoretical model: their reduced econometric form does not capture all the implications of the multi-country Schumpeterian growth model. In contrast, Ertur and Koch propose a richer interdependence scheme by including interactions between countries noted $w_{i j}$ enabling us to conceive of the spatial dependence between country $i$ and country $j$.

Consider a world with $m$ countries. There is one final output $Y$ produced under perfect competition by combining labor and a continuum of intermediate products, according to the production function:

$$
Y_{i}(t)=Q_{i}(t)^{\alpha-1} \int_{0}^{Q_{i}(t)} A_{i}(v, t) x_{i}(v, t)^{\alpha} L_{i}(t)^{1-\alpha} d v
$$

Where $Y_{i}(t)$ is the country's ${ }^{E}$ gross output at date $t, L_{i}(t)=L_{i}(0) e^{n_{i} t}$ is the flow of raw labour used in production and $n_{i}$ its rate of growth, $Q_{i}(t)$ is the number of different intermediate products produced and used in country $i$ at date $t, x_{i}(v, t)$ is the flow output of intermediate product $v \in\left[0, Q_{i}(t)\right]$ used at date $t$, and $A_{i}(v, t)$ is a productivity parameter attached to the latest version of intermediate $\operatorname{good} v \in\left[0, N_{t}\right]$.

Innovations result from domestic $R \& D$ which uses technological knowledge from all over the world. In other words, there is a worldwide 'leading-edge technology parameter' and it is the maximum value of $A_{i}(v, t)$ at date $t$ defined as: 


$$
A_{\mathrm{i}}(t)^{\max } \equiv \max \left\{A_{\mathrm{i}}(v, t) ; v \in\left[0, \mathbf{Q}_{\mathrm{i}}(t)\right]\right\}
$$

Each innovation in sector $v$ of a country ${ }^{i}$ at date ${ }^{t}$ results in a new generation of $v$ th product in the country, whose productivity parameter is $A_{i}(t)^{\max }$.

Each innovation creates an improved version of the existing product, giving the innovator a monopoly over a superior product which will destroy competitors producing that particular variety of intermediate good. This process is known as vertical innovation and it was Howitt and Aghion's contribution to formalising Schumpeter's notion of creative destruction. Instead of enjoying permanent monopolies, as in models of horizontal innovation, neo-Schumpeterian monopolies only last until the next quality improvement wipes them out (Michl, (2000)).

The Poisson arrival rate $\phi_{t}$ of innovations in each sector is:

$$
\phi_{i}(t)=\lambda_{i} k_{i}(t)^{\theta} ; \lambda_{i}>0
$$

where $\lambda$ is a parameter indicating the productivity of $R \& D$, and where $k_{i}(t)=\frac{s_{i, A}(t)}{Q_{i}(t) A_{i}(t)^{\text {max }}}$ is the productivity-adjusted quantity of final output devoted to R\&D in each sector. $\mathrm{R} \& \mathrm{D}$ expenditure is decreased by the leading-edge productivity parameter to take into account the force of increasing complexity; as technology advances, the resource cost of further advances increases proportionally. This hypothesis prevents growth from exploding as the amount of capital available as an input to R\&D grows without limits.

In order to introduce technological diffusion in the Schumpeterian growth model, Ertur and Koch assume that this productivity parameter is defined as follows:

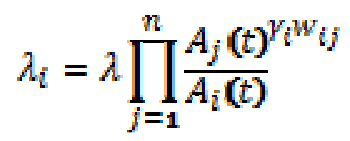

They therefore suppose, as do Aghion and Howitt (1998), that R\&D productivity is a negative function of the technological gap of country $i$ with respect to its own technology frontier. Indeed, the further away a country is from its own technology frontier, the higher its productivity in the research sector because it benefits from the accumulated knowledge in other countries. This technological frontier is defined as the geometric mean of world knowledge levels denoted by $A_{j}(t)$, for $j=1, \ldots, n$. Compared to Aghion and Howitt (1998), this technological frontier is, however, specific to each country as the result of $w_{i j}$ parameters, which model the specific access of country $i$ to the accumulated knowledge of country $j$. The parameter $\gamma_{i}>\mathbf{1}$ measures the absorption capacity of country $i$ which they assume to be a function of its human capital stock. 
This equation shows explicitly that the knowledge accumulated in one country depends on the knowledge accumulated in other countries. The multi-country Schumpeterian growth model implies technological interdependence between countries, so each country cannot be analysed in isolation (Ertur and Koch, 2007).

\section{Econometric specification and estimation issues}

Based on the steady state equilibrium equation (see Ertur and Koch, 2011), the econometric reduced form of the multi-country Schumpeterian growth model applied to our study describes TFP of country $i$, at a given time $t$ as:

$$
\ln T F P_{t i}=\beta_{0}+\beta_{1} \ln \frac{K_{t i}}{n_{t i}+0.05}+\beta_{2} \ln s_{A t i}+\beta_{5} \ln n_{t i}+\gamma \sum_{j=i}^{n} w_{i j} \ln T F P_{t j}+u_{t i}
$$

Where: $\ln T F P_{t i}=\ln y_{t i}-0.05 \ln \frac{K_{t i}}{n_{t i}+0.05}$ is the TFP of country $i$ at time ${ }^{t}$.

$\begin{array}{ll}\frac{K_{t i}}{n_{t i}+0.05}: & \begin{array}{l}\text { Investment rate in physical capital over } \\ \text { country } i \text { and working-age populatio }\end{array} \\ s_{A t i} \quad: \quad & \text { Investment rate in the R\&D sector. } \\ n_{t i} \quad: \quad & \text { Working-age population growth. } \\ u_{t i} \quad: \quad & \text { Regression disturbance. }\end{array}$

The model introduces a spatial lag of the dependent variable defined in the term $\gamma \sum_{j=i}^{n} w_{i j} \ln T F P_{t j}$

with $\gamma$ representing the spatial autocorrelation coefficient and $w_{i j}$ the $i j$ th element of the spatial weight matrix whose diagonal elements are zero. This results from the fact that the R\&D of one country spills over national borders.

Our application covers a panel of nine countries observed over 21 years. Hence, $t=1990, \ldots 2010$ and $i=1, \ldots 9$. The index $i$ represents the countries of South America: Argentina, Bolivia, Brazil, Chile, Colombia, Ecuador, Paraguay, Uruguay and Venezuela. ${ }^{6}$

We extend Ertur and Koch's empirical model by introducing different sources of R\&D funding, which enriches the analysis of the role of R\&D in South America by identifying the impact of domestic (public and private sectors) and foreign $R \& D$ investment in the country. Our measure of R\&D investment rate $\left(s_{A t i}\right)$ is therefore divided into three distinct indicators:

$p u b_{t i}$ : Rate of public sector investment in R\&D.

\footnotetext{
${ }^{6}$ Peru is not analysed because data on R\&D investment are not available.
} 
priv $v_{t i}$ : Rate of private sector investment in R\&D.

for $_{t i}$ : Rate of foreign investment in R\&D.

By distinguishing between national and foreign funding sources, besides the R\&D carried out in other countries, we can identify not only the effect of domestic R\&D and external R\&D on one country's economy but, within the country, to what extent the role of $R \& D$ funding from national sources is significant in comparison to $R \& D$ funding from foreign sources. The differentiation between external knowledge and internal knowledge in a country is thus introduced. It is important to note that throughout this study, we refer to 'foreign R\&D' for R\&D carried out inside the country but funded by foreign sources, and 'external R\&D' for $R \& D$ carried out outside the country. In addition, we use panel data for South American countries from 1990 to 2010, thus introducing a temporal dimension which has important implications for the estimation method.

In order to implement our multi-country Schumpeterian growth model, we rely on the panel data model with error components which are both spatially and temporally correlated, as proposed by Kapoor et al. (2007). They broaden the generalised method-of-moments estimators suggested in Kelejian and Prucha (1998). In their seminal paper, Kapoor et al. (2007) concentrate on the random effects model, assuming that explanatory variables and unit-specific error terms are independent. However, in applied work this assumption often does not hold and a fixed effects specification is employed instead (Mutl and Pfaffermayr, 2011).

Consider the following spatial model:

$y_{i t, N}=\lambda \sum_{j=1}^{N} w_{i j, N} y_{j t, N}+x_{i t, N} \beta+d_{i, N} \gamma+u_{i t, N}$

Index $i=1, \ldots, N$ denotes the cross-sectional dimension of the panel while the index $t=1, \ldots, T$ refers to the time series dimension of the panel. Throughout we assume that $T$ is fixed; i.e., the asymptotic analysis refers to large $N, y_{i t, N}$ is the (scalar) dependent variable and $\sum_{j=1}^{N} w_{i j, N} y_{j \hbar N}$

denotes the spatial lag of the dependent variable with $w_{i j, N}$ being observable nonstochastic spatial weights. $\lambda$ is the associated scalar parameter. $x_{i t_{n} N}$ denotes a $1 \times(K-1)$ vector of time-varying exogenous variables and $\beta$ is the corresponding $(K-1) \times 1$ parameter vector. $d_{i, N}$ is $1 \times L$ vector of time-invariant variables, including the constant, with $L \times 1$ parameter vector. Finally, $u_{i t, N}$ is the overall disturbance term (Mutl and Pfaffermayr, 2011).

They allow for a cross-sectional correlation of the disturbances. In particular, disturbances are assumed to follow a Cliff and Ord-type spatial autocorrelation (SAR(1)) using the terminology of Anselin (1988) as proposed by Kapoor et al. (2007): 


$$
u_{i t_{n} N}=\rho \sum_{j=1}^{N} m_{i j, N} u_{j t_{n} N}+\varepsilon_{i t_{n} N}
$$

where $\rho$ is a scalar parameter and $m_{i j, N}$ are observable spatial weights (possibly the same as the weights $w_{i j, N}$ ). The perturbations $\varepsilon_{i t, N}$ have the following one-way error component structure:

$$
\varepsilon_{i t, N}=\mu_{i, N}+v_{i t, N}
$$

where $v_{i t, N}$ are independent errors and $\mu_{i, N}$ are individual effects, which can be either fixed or random.

\section{Data and specification of the spatial weight matrices}

The analysis is based on information from nine countries: Argentina, Bolivia, Brazil, Chile, Colombia, Ecuador, Paraguay, Uruguay and Venezuela, from 1990 to 2010. The data recorded for these countries was extracted from different sources. GDP and the Gross Capital Formation variables were collected from the World Bank's World Development Indicators (WDI) and Global Development Finance (GDF) database. For R\&D investment by funding sources and also for the working-age population variable, the Iberoamerican and Interamerican Network of Science and Technology Indicators Network (RICYT in Spanish) was used. It is important to note that, due to missing data, Venezuela's R\&D data correspond to the STA indicator, ${ }^{7}$ considered as an approximation of R\&D. Hence, we have to be cautious with the results for this country and regard them as an approximation.

To obtain the real GDP per worker, real GDP is divided by the number of workers (work-age population 15 to 64 years old). We measure $n_{t i}$, for $i=1, \ldots, n$, as the growth rate of the working-age population of the year ${ }^{t}$ with respect to the year $t-\mathbf{1}$. The saving rate $K_{t i}$, for $i=1, \ldots, n$, is measured as the share of gross investment in GDP in the period $t$. The variable $p u b_{t i}$, is measured as the share of domestic expenditure by the public sector on R\&D relative to GDP of the country $i$ over the period $t$. The variable $p r i v_{t i}$, is measured as the share of domestic expenditure by the private sector on R\&D relative to GDP of the country $i$ over the period $t$. The variable for $_{t i}$, is measured as the share of domestic expenditure by foreign funding sources on $\mathrm{R} \& \mathrm{D}$ relative to GDP of the country $i$ over the period $t$. Finally, in line with Mankiw et al. (1992) among others, we use the sum of the depreciation rate of physical capital $\delta$ and the world growth rate $g_{w}, g_{w}+\delta=0.05$. For the capital investment depreciated term, $\frac{K_{t j}}{n_{\tau j}+0.05}$ we multiply it by $H_{i}$, the human capital stock of the destination country. The latter is measured by

\footnotetext{
${ }^{7}$ Scientific and Technological (S\&T) activities: In addition to R\&D, scientific and technological activities include scientific and technical education and training (STET) and scientific and technological services (STS). The latter services include, for example, S\&T activities of libraries and museums, translation and editing of S\&T literature, surveying and prospecting, data collection on socio-economic phenomena, testing, standardisation and quality control, client counseling and advisory services, and patents and licensing activities by public bodies (Frascati 2002).
} 
the number of expected years of schooling of children extracted from the UNESCO database (available at http://hdr.undp.org).

Since the model to be used contains an interdependence pattern, a spatial weight matrix, known as the $\mathrm{W}$-matrix, is constructed. Spatial weight matrices represent a convenient and parsimonious way to define the spatial dependence between observations (Lesage and Pace, 2004). This matrix shows that each country is connected to a set of neighbouring countries by means of an exogenous pattern introduced in W. Elements on the main diagonal are set to zero by convention whereas elements $w_{i j}$ indicate the way country $i$ is connected to country $j$. There are many ways of specifying dependence, such as contiguity, among regions, nearest neighbours, other functions of distance or any other criteria that could explain a pattern of spatial dependence. For interpretive and numerical reasons, a common practice is to row-standardise the $\mathrm{W}$-matrix, so that row sums are unity (see Anselin, 1988). Typically, the strategy for constructing a spatial weight matrix depends on the type of variable being modelled. In this study, because we are interested in understanding the mechanisms of international technology diffusion, we did not chose one specific W-matrix but tested different specifications in order to identify which was the most relevant. Keller (2002) in particular identified the role played by geographical distance between countries as the productivity effects of $R \& D$ decline with distance. However, alongside physical proximity, international technology diffusion literature has also pointed out the key role played by international trade and FDI (MacGarvie, 2003, and Coe et al., 1997, Keller, 2004). We therefore rely on three different weight matrices.

One of these is the geographical distance matrix, which is calculated to be row standardised matrix. Two measures of distance were available: on the one hand, the geodesic distance which simply considers the latitude and longitude of the country's main city, and on the other, the weighted distance using city-level data to assess the geographical distribution of the population within each country (CEPII, http://www.cepii.fr). The latter is used in this study. The idea is to calculate distance between two countries based on bilateral distances between the largest cities of those two countries, those inter-city distances being weighted by the share of the city in the country's total population.

The second criterion is contiguity. In this weight matrix the $w_{i j}$ elements equal 1 if country $i$ and country $j$ share a border and 0 , otherwise. The row standardised contiguous matrix is used, so that the spatially lagged explanatory variable is a weighted sum of the explanatory variable observed in neighbouring countries.

The last specification of our weight matrix relies on imports. Each element $w_{i j}$ represents the average fraction of country $j$ 's imports coming from country $i$ with $i \neq j$, otherwise $w_{i j}=\mathbf{0}$. The database of imports was obtained from the World Bank's WITS software (World Integrated Trade Solution). This specification raises an important issue for spatial models. The validity of the estimation techniques requires that the weight matrix be based on exogenous information. This assumption is relevant for spatial information such as distance and contiguity, but is obviously more questionable for imports. ${ }^{8}$ The similarity of our estimation results using the three

\footnotetext{
${ }^{8}$ This would have been even more doubtful for FDI. In particular, R\&D intensity as well as the investment rate in physical capital may be directly driven by FDI. This explains why we focus here on imports only.
} 
different matrices provides us with a certain robustness check, but it must be borne in mind that the use of an import weight matrix may potentially lead to endogeneity problems. In addition, in contrast to physical distance, trade proximity is likely to change over time. Here only one year, 2010, is used to build our import weight matrix. It would be relevant to extend this to considering a spatio-temporal weight matrix, which would also enable the weight matrix to be endogenised. However, endogenous W-matrices remain an unsolved issue in spatial econometrics and are outside of the scope of this study.

\section{Estimation results}

Based on the methodology presented above, we analyse the econometric results of the estimation of the TFP model.

Due to the panel dimension of our dataset, the usual spatial autocorrelation tests are not suitable. Baltagi, Song and Koh (2001) considered the problem of jointly testing for random effects in the panel as well as spatial correlation across regions. We follow their approach and perform a joint Lagrange Multiplier (LM) test which simultaneously tests for the existence of spatial error correlation as well as random region effects. This test is important, because ignoring spatial correlation and heterogeneity due to the random region effects will result in inefficient estimates and misleading inferences (Baltagi et al., 2001). This test leads us to reject the null hypothesis of absence of random regional effects and absence of spatial autocorrelation ( $\mathrm{LM}-\mathrm{H}=928.504$, $\mathrm{p}-$ value $<2.2 \mathrm{e}-16)$.

The results presented in table 1 are thus obtained from a model which considers spatial dependence between spatial units and allows heterogeneity across the spatial units using random effects. As mentioned above, the weight matrix could be specified according to different criteria. In this study, instead of choosing a priori one specific configuration, different specifications are tested and the estimation results are shown in Table 1: the first column reports the results obtained using inverse distance, the second model relies on the contiguity weight matrix, and the last column provides estimates based on the import matrix. The goodness of fit of the models is similar, at 59.7\%, 58.6\% and 57.7\%, respectively. It can, however, be noted that different specifications of the weight matrix provide different results. The spatial autocorrelation parameter $\gamma$ and the coefficient of private $\mathrm{R} \& \mathrm{D}$ funding are not significant in the first model using our distance weight matrix, but turn out to be significant and positive when using the contiguity and import matrices. In these two specifications, coefficient $\gamma$ measuring the degree of technological interdependence between countries is high and significant. These results are qualitatively equivalent to those from the Ertur and Koch 2011 model. As Ertur and Koch (2011) state, countries cannot be considered as isolated observations. Our estimations therefore provide evidence of technological dependence between South American countries, due to border sharing 
and import relationships. International R\&D spillovers would then be supported by both physical and commercial distance.

Table 1. Total Factor Productivity - Spatial Panel Random Effects Model

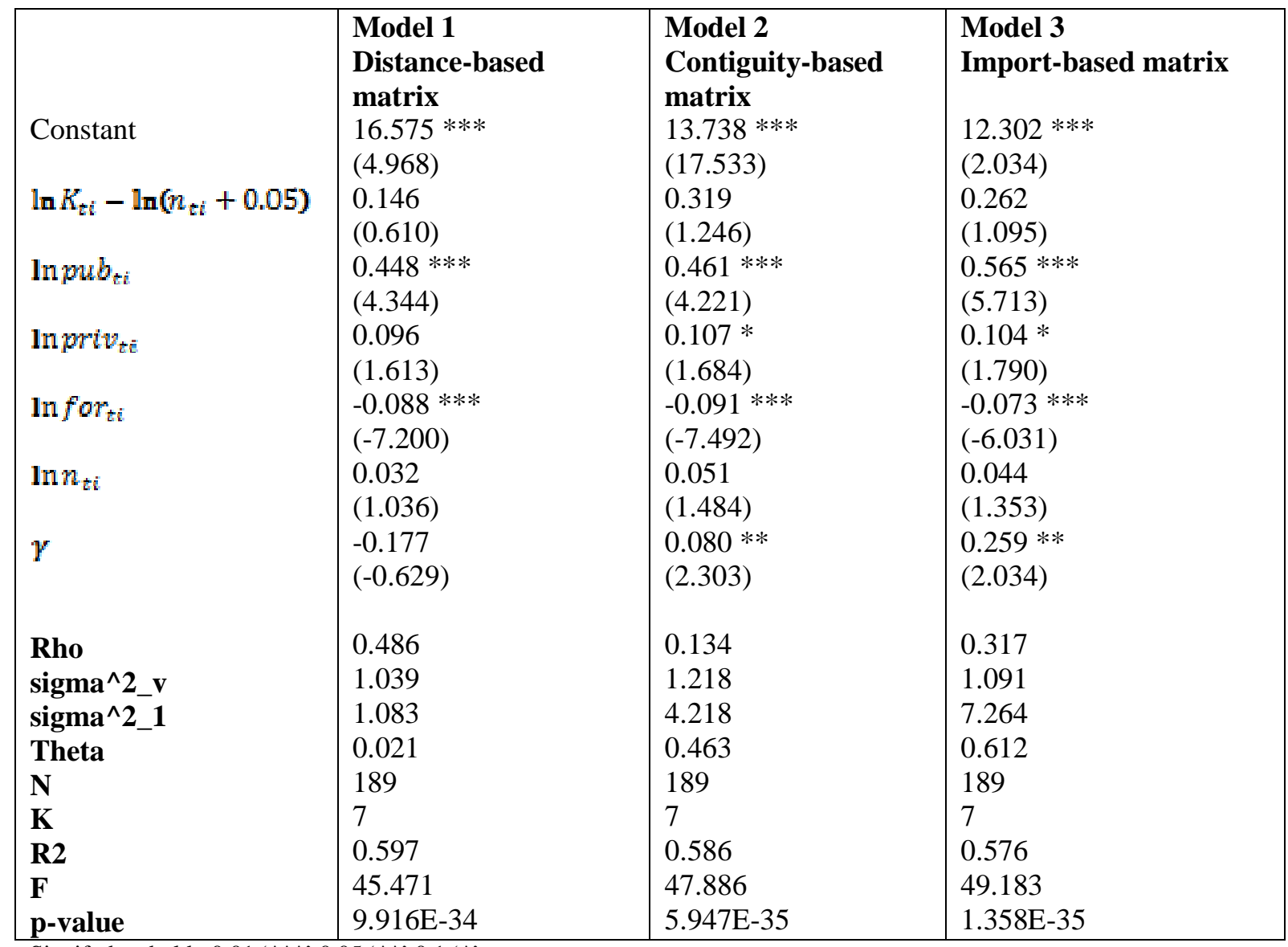

Signif. threshold: $0.01^{\text {'**** }} 0.05^{\text {'***’ }} 0.1^{\text {'** }}$

The coefficients of the logarithm of the capital investment depreciated term and of working-age population growth are not significant whichever model is used. This could be explained by the time and space dimensions of our data which allow us to control for individual effects. Our country effects would capture the net effects of all the other factors not specified in the model and impacting upon national TFP. Once these effects have been accounted for, the specific role played by capital investment and workforce growth would be of second-order only.

Moreover, we can see that the effect of R\&D investment upon South American countries' economies is significant, showing that $R \& D$ does have an impact on productivity. Of the effects we can distinguish that caused by public, private and foreign funding. Public investment in R\&D plays a fundamental role in the national development strategy of any country within the region. According to the observed coefficients, we can say that an increase of $1 \%$ in publicly funded 
R\&D increases TFP by around $0.5 \%$, all else being equal. Private R\&D investment in these countries is not as significant as public investment but also has a positive effect. This provides evidence that locally-funded $R \& D$ investment does influence the Poisson arrival rate of new knowledge and plays an important role in growth and the development process which is consistent with the multi-country Schumpeterian growth model.

Conversely, the coefficient of foreign $R \& D$ investment is negative. This is more unexpected, but is in accordance with the fact that most countries of the region experienced a decrease in $R \& D$ funding from foreign sources during the 1990-2010 period. This negative effect may be consistent with critics of the neo-liberal position who consider that foreign investment initially produces greater growth, but has less optimist implications in the long run. They argue that profits are repatriated to the investing country rather than being re-invested locally. Income increasingly accrues to only the wealthiest individuals, who help to construct economic, political and social policies which benefit outside interests rather than meeting domestic needs. From another point of view, it has been suggested that it is the composition, or structure, of foreign investment which has the greatest impact on developing countries' economies, rather than the total amount of foreign capital received. ${ }^{9}$ In the case of foreign $R \& D$ expenditure, other structural aspects of foreign investment may also have a significant impact on development. For instance, the capacity of the host country to assimilate knowledge transfers or the sectors into which foreign investment is directed may be important factors.

\subsection{International R\&D spillovers}

The model implies that the $R \& D$ of one country spills over to other countries. The relative importance of foreign technology diffusion can be evaluated by comparing the TFP elasticities of domestic and external R\&D. Indeed, we evaluate TFP elasticity of the home country $i$ with respect to domestic and external $R \& D$ expenditure. Since in this study we differentiate $R \& D$ by funding source: $R \& D$ funded by the public sector, $R \& D$ funded by the private sector, and $R \& D$ funded by foreign sources, we can compare the impact on TFP of the home country in terms of domestic public $R \& D$ expenditure and external public $R \& D$; domestic private $R \& D$ expenditure and external private $R \& D$; and foreign sources of $R \& D$ funding and external foreign sources of $R \& D$ funding. The estimated matrix of elasticities, using the coefficients of the econometric reduced form (5) is as follows:

$$
\mathbf{\Xi}_{\mathrm{TFP}}=\hat{\beta}_{2}(I-\hat{\gamma} W)^{-1}
$$

\footnotetext{
${ }^{9}$ In other words, the higher the level of foreign investment concentrated within a country, the lower its rate of economic growth and vice versa (Kentor, 2003).
} 
For other types of $R \& D$, we follow the same structure. In order to know whether the indirect effects of the TFP are significant, the Delta Method ${ }^{10}$ is used.

We thus quantify the impact of home and foreign R\&D expenditure on the TFP of a given country, using the weight matrix structure. We analyse the standard configuration of diffusion among South American countries where every country spills over into all others. ${ }^{11}$

In order to compute these elasticities, we rely on our import W-matrix. The effects could also be computed with the contiguity W-matrix. For reasons of brevity, these results are not presented in their entirety, but are available upon request.

\section{Impact of public sector R\&D funding}

The following matrix presents the cross-partial derivatives and own-partial derivatives that inform us about the extent to which each country diffuses its own technology and benefits from international R\&D diffusion. The flow of knowledge between countries $i$ and $j$ goes from the country in column $j$ to the country in row $i$ and the diagonal of the matrix represents spillovers within a country, which is the TFP elasticity of a given country with respect to its own public $\mathrm{R} \& \mathrm{D}$ expenditure. Each term of the matrix is associated with its statistical significance using the Delta Method, where the asterisk represents significance at $5 \%$.

Table 2. International $R \& D$ with public source funding spillovers-Import W-matrix

\begin{tabular}{|c|c|c|c|c|c|c|c|c|c|c|c|c|c|c|c|c|c|c|}
\hline & Arg & & Bol & & Bra & & Chi & & Col & & Ecu & & Par & & Uru & & Ven & \\
\hline Arg & 0.576 & $*$ & 0.005 & $*$ & 0.080 & $*$ & 0.027 & $*$ & 0.010 & $*$ & 0.005 & $*$ & 0.010 & & 0.028 & $*$ & 0.020 & \\
\hline Bol & 0.013 & * & 0.566 & $*$ & 0.107 & $*$ & 0.009 & $*$ & 0.015 & $*$ & 0.003 & * & 0.003 & $*$ & 0.008 & $*$ & 0.037 & \\
\hline Bra & 0.068 & $*$ & 0.005 & & 0.582 & $*$ & 0.022 & & 0.011 & $*$ & 0.005 & & 0.011 & & 0.022 & & 0.034 & \\
\hline Chi & 0.023 & $*$ & 0.006 & $*$ & 0.073 & $*$ & 0.570 & $*$ & 0.015 & $*$ & 0.012 & & 0.004 & & 0.012 & * & 0.046 & * \\
\hline Col & 0.005 & $*$ & 0.003 & & 0.019 & $*$ & 0.015 & $*$ & 0.569 & $*$ & 0.020 & $*$ & 0.002 & $*$ & 0.013 & * & 0.115 & * \\
\hline Ecu & 0.011 & $*$ & 0.003 & $*$ & 0.015 & $*$ & 0.041 & $*$ & 0.043 & $*$ & 0.569 & $*$ & 0.002 & $*$ & 0.010 & $*$ & 0.068 & * \\
\hline Par & 0.037 & $*$ & 0.004 & $*$ & 0.054 & $*$ & 0.045 & $*$ & 0.005 & $*$ & 0.003 & $*$ & 0.567 & $*$ & 0.015 & $*$ & 0.032 & * \\
\hline Uru & 0.038 & $*$ & 0.003 & * & 0.083 & * & 0.012 & $*$ & 0.006 & $*$ & 0.005 & * & 0.009 & $*$ & 0.572 & $*$ & 0.034 & * \\
\hline Ven & 0.010 & $*$ & 0.012 & & 0.044 & $*$ & 0.011 & & 0.014 & & 0.021 & & 0.010 & & 0.062 & $*$ & 0.576 & \\
\hline
\end{tabular}

High diffusion

\footnotetext{
${ }^{10}$ The Delta Method is an intuitive technique for approximating the moments of functions of random variables when direct evaluation of the expectation is not feasible. For linear functions $g$ of a random variable $X, E[g(X)]=g(E[X])$. The Delta Method approximates the expectation of $\mathrm{g}(\mathrm{X})$ by taking the expectation of a polynomial approximation to $\mathrm{g}(\mathrm{X})$. The polynomial is usually a truncated Taylor series centered at the mean of X. For more details see Oehlert, (1992).

${ }^{11}$ Other configurations can be tested in order to identify clubs of convergence. The results are not presented here as they do not provide evidence of a specific spatial configuration in South America.
} 
Initially, we see that most $R \& D$ spillover terms are significant, which means that international spillovers play an important role in terms of TFP between most countries in the area. An increase in research in other countries of the region leads a greater inflow of technologies and higher TFP of the domestic country. However, the intensity of the effect depends on the particular relationship between countries.

Brazil is the country with the greatest diffusion of public R\&D to other countries. This is because Brazil holds an important position in the international trade pattern with a share of $41.9 \%$ of regional imports between 1990 and 2010. According to Guevara and Jarrin (2011), Brazil is the country with the highest share of manufacturing in its total exports, which allows other countries to benefit from its knowledge spillovers. We note that Brazil impacts greatly on the TFP of Bolivia, Uruguay, Argentina and Chile. This is partly due to the intensity of trade between these countries and Brazil. Brazil's participation in Bolivia's imports during the period was $41.5 \%$, in Uruguay's imports it was 44.4\%, in Argentina's imports it was $78.5 \%$, and in Chile's imports it was $35.4 \%$. However, trade intensity is not the only driver. The fact that Bolivia benefits the most, despite the fact that its import rate from Brazil is not the highest, proves that the further away a country is from its own technology frontier the higher its productivity in the research sector because it can benefit from the accumulated knowledge in other countries.

We also note that other countries which significantly diffuse their public R\&D across the region are Chile and Venezuela. The countries that benefit most from Chile's spillovers are Ecuador and Paraguay, while the countries that benefit most from Venezuela's spillovers are Colombia, Ecuador and Chile. In contrast, Bolivia is a country with very low knowledge spillover to other countries. Some reciprocal relationships with relatively high elasticities in both directions can also be observed: between Argentina and Brazil on the one hand and between Colombia and Ecuador on the other. In general, we observe that knowledge diffuses locally between South American countries where elasticities show a medium diffusion level.

\section{Impact of private sector $R \& D$ funding}

We then evaluate the elasticity of TFP of the home country $i$ with respect to domestic expenditure from the private sector and external R\&D expenditure from other countries' private

sectors. Thus, we can assess the direct and indirect impact of private investment in the R\&D sector on each country's productivity. 
Table 3. International $R \& D$ with private source funding spillovers-Import $W$-matrix

\begin{tabular}{|l|llllllllll|}
\cline { 2 - 12 } \multicolumn{1}{c|}{} & Arg & Bol & Bra & Chi & Col & Ecu & Par & Uru & Ven \\
\hline Arg & $\mathbf{0 , 1 0 6 5}$ & 0,0009 & $0,0148 *$ & $0,0050 *$ & $0,0019 *$ & 0,0009 & 0,0018 & 0,0053 & $0,0038 *$ \\
Bol & $0,0024 *$ & $\mathbf{0 , 1 0 4 6}$ & $0,0198 *$ & $0,0016 *$ & $0,0028 *$ & $0,0006 *$ & $0,0006 *$ & $0,0015 *$ & $0,0068 *$ \\
Bra & 0,0126 & 0,0009 & $\mathbf{0 , 1 0 7 5}$ & 0,0041 & 0,0021 & 0,0010 & 0,0020 & 0,0041 & 0,0064 \\
Chi & 0,0043 & 0,0012 & $0,0136 *$ & $\mathbf{0 , 1 0 5 3}$ & 0,0028 & 0,0021 & 0,0008 & 0,0022 & $0,0085 *$ \\
Col & 0,0009 & 0,0006 & $0,0035 *$ & 0,0028 & $\mathbf{0 , 1 0 5 1}$ & 0,0036 & $0,0004 *$ & $0,0024 *$ & $0,0212 *$ \\
Ecu & $0,0021 *$ & 0,0005 & $0,0028 *$ & $0,0076 *$ & $0,0079 *$ & $\mathbf{0 , 1 0 5 1}$ & $0,0003 *$ & $0,0018 *$ & $0,0126 *$ \\
Par & $0,0068 *$ & 0,0007 & $0,0100 *$ & $0,0083 *$ & $0,0009 *$ & $0,0005 *$ & $\mathbf{0 , 1 0 4 7} *$ & $0,0027 *$ & $0,0060 *$ \\
Uru & $0,0070 *$ & 0,0005 & $0,0153 *$ & 0,0023 & 0,0011 & 0,0009 & 0,0017 & $\mathbf{0 , 1 0 5 7}$ & 0,0062 \\
Ven & 0,0018 & 0,0022 & $0,0082 *$ & 0,0021 & 0,0027 & 0,0040 & $0,0019 *$ & $0,0115 *$ & $\mathbf{0 , 1 0 6 5}$ \\
\hline
\end{tabular}

When compared with the impact of public R\&D on TFP, the impact of private R\&D expenditure is lower and is less significant. In terms of the intensity level of the spillovers, similar results are found, Brazil being the country with the greatest diffusion of private $R \& D$ to other countries of the region.

\section{Impact of foreign R\&D funding}

A different pattern is found when analysing the impact of foreign investments in R\&D on TFP. As pointed out in section 3, foreign $R \& D$ investment produces a negative effect on TFP, resulting in negative spillovers between countries. Luintel and Khan (2004) argue that growth theories which advocate positive international knowledge spillovers neglect issues of technological and industrial rivalry. Unfortunately, technological rivalry is a world reality and knowledge diffusion, in principal, can be positive or negative. If an R\&D strategy is designed to pre-empt competition, then spillovers can be negative (Luintel and Khan, 2004). In the case ofSouth America, foreign investments in $R \& D$ would generate such a negative indirect effect. Due to the import structure, Bolivia is once more the country which faces the highest effects, followed by Venezuela. 
Table 4. International $R \& D$ with foreign source funding spillovers-Import W-matrix

\begin{tabular}{|c|c|c|c|c|c|c|c|c|c|}
\hline & Arg & Bol & Bra & Chi & Col & Ecu & Par & Uru & Ven \\
\hline Arg & $-0,074 *$ & $-0,001 *$ & $-0,010 *$ & $-0,004 *$ & $-0,001 *$ & $-0,001 *$ & $-0,001$ & $-0,004 *$ & $-0,003 *$ \\
\hline Bol & $-0,002 *$ & $-0,073 *$ & $-0,014 *$ & $-0,001 *$ & $-0,002 *$ & $-0,0004 *$ & $-0,0004 *$ & $-0,001 *$ & $-0,005 *$ \\
\hline Bra & $-0,009 *$ & $-0,001$ & $-0,075 *$ & $-0,003$ & $-0,001 *$ & $-0,001 *$ & $-0,001$ & $-0,003$ & $-0,004 *$ \\
\hline Chi & $-0,003 *$ & $-0,001 *$ & $-0,009 *$ & $-0,073 *$ & $-0,002 *$ & $-0,001$ & $-0,001$ & $-0,002 *$ & $-0,006 *$ \\
\hline Col & $-0,001 *$ & $-0,0004$ & $-0,002 *$ & $-0,002 *$ & $-0,073 *$ & $-0,003 *$ & $-0,0003 *$ & $-0,002 *$ & $-0,015 *$ \\
\hline Ecu & $-0,001 *$ & $-0,0004 *$ & $-0,002 *$ & $-0,005 *$ & $-0,006 *$ & $-0,073 *$ & $-0,0002 *$ & $-0,001 *$ & $-0,009 *$ \\
\hline Par & $-0,005 *$ & $-0,0005 *$ & $-0,007 *$ & $-0,006 *$ & $-0,001 *$ & $-0,0004 *$ & $-\mathbf{0 , 0 7 3} *$ & $-0,002 *$ & $-0,004 *$ \\
\hline Uru & $-0,005 *$ & $-0,0004 *$ & $-0,011 *$ & $-0,002 *$ & $-0,001 *$ & $-0,001 *$ & $-0,001 *$ & $-0,074 *$ & $-0,004 *$ \\
\hline Ven & $-0,001 *$ & $-0,002$ & $-0,006 *$ & $-0,001$ & $-0,002$ & $-0,003$ & $-0,001$ & $-0,008 *$ & $-0,074 *$ \\
\hline \multicolumn{10}{|c|}{ High diffusion } \\
\hline & & \multicolumn{8}{|c|}{ Medium diffusion } \\
\hline & & \multicolumn{8}{|c|}{ Low diffusion } \\
\hline
\end{tabular}

\section{CONCLUSION}

In spite of its small share in world R\&D expenditure, South America increased its R\&D per GDP ratio by $83 \%$ between 1990 and 2010. New growth theory and, more specifically, growth models with endogenous technical change thus appear as a suitable tool to explain South America's growth. Based on Ertur and Koch's Schumpeterian growth model, we study the impact of R\&D expenditure on countries' TFP and account for potential dependencies between South American countries. According to our theoretical model, due to international technology diffusion, R\&D expenditure spills over national borders, leading to a spatial structure where the level of productivity in one country generates indirect effects on other countries' productivity. In comparison with Ertur and Koch (2011), our dataset also allows us to investigate the respective role played by different sources of $R \& D$ funding and to control for country unobserved effects using spatial panel data methods.

The main findings are as follows. First of all, R\&D funding from public and private sources plays a key role in the productivity of South American countries. In contrast, we found that R\&D funding from foreign sources has a detrimental impact on regional productivity. The capacity of the host country to assimilate foreign investment thus appears to be a key issue. Secondly, spatial dependence arises which is driven both by physical proximity between countries and trade intensity. Thirdly, the cross-partial and own partial derivatives provide us with an estimation of the extent to which each country in the area produces and benefits from international knowledge spillovers, highlighting the central role played by Brazil. 
The current work contributes to the empirical study on South American growth, taking into account the main issues concerning the recent worldwide pattern of international technology diffusion, and being one of the few pieces of research that focuses on these countries and evaluates the importance of $R \& D$ and technology diffusion on productivity. Through this research we have been able to test, among other issues which determine the growth of South American countries, the effect of different R\&D sources on productivity. We have also been able to quantify international $R \& D$ spillovers between these countries and investigate different channels of technology diffusion in the area. R\&D activities, especially those which are publicly financed, have been shown to act as a main driver of TFP, both directly and indirectly through international technology diffusion. Evidence shows that this latter relies on both physical proximity and trade intensity.

Despite this contribution, some limitations of the paper have to be underlined. First of all, as our main concern was to understand international relationships within the area, we focused on South American countries only. We disregarded other sources of international knowledge spillovers and, in particular, the knowledge transfers that may arise from developed countries. This would obviously be a complementary topic to be investigated. A second issue that deserves further attention is the potential endogeneity of the import-based weight matrix. Spatial econometric tools require that the interaction matrix be exogenous. The endogenous interaction matrix remains a research challenge for spatial econometric analysis.

Although we must remain very cautious in interpreting the results, our study points to some public policies issues. Because public funding for research is the highest component of regional $\mathrm{R} \& \mathrm{D}$, it is important for public resources to be efficient and for governments to introduce policies to make funding more focused. In general, barriers to access to and use of public research infrastructure are an issue. Hence, governments should be encouraged to make this available under appropriate conditions. According to the results, the impact of foreign-funded $R \& D$ on growth and productivity is negative, suggesting changes could be made to the $R \& D$ foreign-funded framework of South American countries. During the negotiation process, certain conditions should be met: firstly, all relevant interests must be represented (condition of representation), secondly, all those involved in the process must have full information about the consequences of various possible outcomes (condition of full information) and finally, no one party must coerce the others (condition of non-domination). In addition, foreign-funded $R \& D$ may produce favourable results if obstacles to international technology cooperation are removed.

\section{REFERENCES}

Aghion, P., and Howitt P., 1998. Endogenous Growth Theory, MIT Press, Cambridge, MA. 
Anselin, L. 1988. Spatial Econometrics: Methods and Models. Kluwer Academic Publishers, Dordrecht.

Baltagi, H., Song, S., Koh, W., December 2001. Testing Panel Data Regression Models with Spatial Error Correlation. Journal of Econometrics, Elsevier. 117 (1), 123-150.

Bianco, D., Niang, A., 2012. On international Spillovers. Economic Letters. Elsevier. 117(1), 280-282

Centre d'études prospectives et d'informations internationales (CEPII). Distances Database. Access: 15 April 2010.

Coe, D., Helpman, E., 1995. International R\&D Spillovers. European Economic Review. 39, 859-887.

Coe, T., Helpman, E., Hoffmaister A., 1997. North-South R\&D Spillovers. Economic Journal, 107, 134-49.

Eaton, J., Kortum, S., 1996. Measuring Technology Diffusion and the International Sources of Growth. Eastern Economic Journal. 22(4), 401-10.

Ertur, C., Koch, W., 2011. A Contribution to the Schumpeterian Growth Theory and Empirics. Journal of Economic Growth. 16(3), 215-255.

Frascati Manual, Proposed Standard Practice for Surveys on Research and Experimental Development, OECD 2002.

Grossman, G., Helpman, E., 1991. Innovation and Growth in the Global Economy. Cambridge: MIT Press 1991.

Howitt, P., 2000. Endogenous Growth and Cross-Country Income Differences. The American Economic Association. 90(4), 829-846.

Kapoor, M., Kelejian, H., Prucha, I., 2007. Panel data models with spatially correlated error component. Journal of Econometrics. 140, 97-130.

Kelejian, H., Prucha, I., 1998. A Generalized Spatial Two-Stage Least Squares Procedure for Estimating a Spatial Autoregressive Model with Autoregressive Disturbances. Journal of Real Estate Finance and Economics. 17(1), 99-121.

Keller, W., 2004. International Technology Diffusion. Journal of Economic Literature. 42, 752782 
Kentor, J., 2003. Foreign Investment Isn't Enough. YaleGlobal. Access: 9 April 2012. Available at: http://yaleglobal.yale.edu/content/foreign-investment-isnt-enough.

Luintel, K., Khan, M., November 2004. Are International R\&D Spillovers Costly for the US?. The Review of Economics and Statistics. 86 (4), 896-910.

Lesage, J. Pace, R., 2004. Spatial and Spatiotemporal Econometrics. Elsevier JAI. pp 3.

Mankiw, G., Romer, D., Weil, D., 1992. A Contribution to the Empirics of Economic Growth. The Quarterly Journal of Economics. 107 (2), 407-437.

Michl, T., 2000. Notes on the New Endogenous Growth Theory. A Review of Philippe Aghion and Peter Howitt, Endogenous Growth Theory. Metroeconomica 51(2), 183-184.

Mult, J., Pfaffermayr, M., 2011. The Hausman test in a Cliff and Ord panel model. Econometrics Journal. 14, 48-76.

Oehlert, G., 1992. A note of the Delta Method. The American Statistician. 46(1), 27-29

RICYT (Iberoamerican and Interamerican Network of Science and Technology Indicators) database. Access : 20 April 2010. 